NBER WORKING PAPER SERIES

\title{
HOW WORKERS FARE WHEN EMPLOYERS INNOVATE
}

\author{
Sandra E. Black \\ Lisa M. Lynch \\ Anya Krivelyova \\ Working Paper 9569 \\ http://www.nber.org/papers/w9569 \\ NATIONAL BUREAU OF ECONOMIC RESEARCH \\ 1050 Massachusetts Avenue \\ Cambridge, MA 02138 \\ March 2003
}

This research was supported in part by the National Science Foundation Program on Innovation and Organizational Change. The research work in this paper was conducted while the authors were Census Bureau Research Associates at the Census Bureau's Boston Research Data Center. Research results and conclusions expressed are those of the authors and do not necessarily indicate concurrence by the U.S. Bureau of the Census or the National Bureau of Economic Research. This paper has been screened to ensure that no confidential data are revealed. The views expressed herein are those of the authors and not necessarily those of the National Bureau of Economic Research.

C2003 by Sandra E. Black, Lisa M. Lynch, and Anya Krivelyova. All rights reserved. Short sections of text not to exceed two paragraphs, may be quoted without explicit permission provided that full credit including Cnotice, is given to the source. 
How Workers Fare When Employers Innovate

Sandra E. Black, Lisa M. Lynch, and Anya Krivelyova

NBER Working Paper No. 9569

March 2003

JEL No. J3, J5

\section{ABSTRACT}

Complementing existing work on firm organizational structure and productivity, this paper examines the impact of organizational change on workers. We find evidence that employers do appear to compensate at least some of their workers for engaging in high performance workplace practices. We also find a significant association between high performance workplace practices and increased wage inequality. Finally, we examine the relationship between organizational structure and employment changes and find that some practices, such as self-managed teams, are associated with greater employment reductions, while other practices, such as the percentage of workers involved in job rotation, are associated with lower employment reductions.

Sandra E. Black

Department of Economics

UCLA

Los Angeles, CA 90095

and NBER

sblack@econ.ucla.edu
Lisa Lynch

Fletcher School

Tufts University

Medford, MA 02155

and NBER

lisa.lynch@tufts.edu
Anya Krivelyova

Department of Economics

Boston College

Chestnut Hill, MA 02167

krivelyo@bc.edu 


\section{Introduction}

In response to intensified foreign and domestic competition, many American companies have tried to improve company performance through the more effective use of their workforce. Businesses have re-organized and reengineered their workplaces to incorporate what have been labeled High Performance Workplace (HPW) practices. Examples of such workplace practices include employee involvement programs, job rotation, self-managed teams, company provided training, and incentive-based compensation plans. Organizations that utilize HPW practices may make more efficient use of labor by drawing upon the ideas of a broader range of employees than more traditional forms of work organization.

Evidence in the literature suggests that the organizational structure of a firm has a

significant impact on labor productivity. ${ }^{1}$ This finding leaves one wondering: How do workers fare? This paper addresses this issue by answering the following questions. First, how does a more interactive organizational structure affect the level of wages? Second, how does this type of organizational structure affect relative wages within an establishment? Third, how is organizational structure related to employment changes?

We hypothesize that HPW practices are likely to benefit workers because workers would be less willing to contribute in the manner these practices require unless they are assured a share of the gains (this is also argued in Osterman, 2000). We examine this directly and find that wages of workers employed in businesses that use HPW practices are higher than wages for workers employed in more traditionally organized firms. This 
is especially true for managers, supervisors, and technical workers in unionized establishments.

Researchers have posited many theories as to why wage inequality has increased since 1980 in the United States. Much of the debate on the worsening position of unskilled workers has focused on the role of technological factors (see Berman, Bound and Griliches (1994)), along with other factors such as trade, declining unionzation, and falling real minimum wages. In this paper, we add an additional dimension to the discussion on inequality - the role of innovation in the organization of work. As argued in Aghion, Caroli and García-Peñalosa (1999), the impact of organizational change on inequality is theoretically ambiguous, both for an economy as a whole and for specific employers. This, therefore, becomes an empirical question. When we examine how organizational change has affected the relative wages of nonproduction versus production workers, we find that implementing a wide range of HPW practices does seem to be associated with higher inequality within employers.

Organizational change can both alter the skill requirements within different occupational classifications and the relative demand for different occupational classes. Work by Caroli and Van Reenen (1999) and Osterman (2000) suggests that organizational change may be "skilled biased". When we examine the association between HPW and employment changes, we find a mixed picture. Some practices, such as self-managed teams, are associated with greater employment reductions while other practices, such as the percentage of workers involved in job rotation, are associated with lower employment reductions. 
To examine these three outcomes (wages, wage inequality and employment changes), we use a unique nationally representative sample of manufacturing establishments drawn from the Educational Quality of the Workforce National Employer Survey, EQW-NES. This survey is composed of two waves of interviews of representative samples of U.S. manufacturing and non-manufacturing establishments in 1993 and 1996, including a panel of approximately 700 establishments. The survey has a higher response rate than most previous surveys, and it contains very detailed information on specific employer workplace practices, including changes in the organization of work and investments in new technology. The remainder of the paper is organized as follows: Section 2 briefly surveys previous work on the three outcomes of interest and their relationship to workplace practices, Section 3 summarizes the data used, Section 4 presents the empirical findings, and Section 5 concludes.

\section{Background Discussion}

\section{Workplace Innovation and Wages}

One might expect that those practices which raise the productivity of a firm would have an impact on pay for a number of reasons. First, if there were any applicability of the skills associated with high performance workplace practices outside the firm, workers would command a higher wage. Non-managerial workers who have learned how to work in self-managed teams may also become more valuable to other employers as they acquire problem solving and interpersonal skills. Additionally, to overcome resistance to change, supervisors may have to be paid a wage premium to ensure that they actively participate in (rather than undermine) work practices that require them to be a facilitator of groups of workers engaged in problem solving. These worker groups might otherwise 
be viewed as a challenge to the authority and job security of a supervisor. Firms that are undergoing substantial re-organization may also have to pay a compensating wage differential to make-up for the increased job insecurity associated with rapid work reorganization. At the same time, workplaces that are undergoing substantial change in work organization may generate increased concerns about job security that may temper worker demands for increased wages.

Wages could also be higher to reflect efficiency wages, where increased responsibility and firm-specific capital generated by the introduction of high performance workplace practices increases the cost to the firm of worker turnover. (In contrast, turnover costs might also be lower if job rotation reduces unique skills and new work practices move knowledge away from workers.) In addition, one could consider a rentsharing argument as to why wages could be higher; workers, especially unionized workers, may be able to bargain for a share of the higher productivity generated by the use of high performance workplace organization. Finally, employers who introduce profit-sharing or stock options to their employees may at the same time lower average regular wages (excluding profit sharing) to increase incentives while paying workers a sufficiently high expected wage as to maintain market compensation

There has been relatively little work that has examined the impact of workplace innovation on the pay of workers. One way to examine the impact of technological and organization change is to examine the impact of these factors on the rate of growth of average wages. For example, Osterman (2000) has examined the impact of work reorganization on the change in wages from 1992-1997 and found little impact of HPW practices on wages. Cappelli and Neumark (1999) using the EQW-NES (but for a 
restricted sample of manufacturing establishments that have been in existence since at least 1977) find some evidence that workplace practices, such as benchmarking and total quality management, are positively related to average labor costs per worker. But their study does not examine changes in wages and how they are affected by changes in workplace practices over time, nor do they examine how the pay of different categories of workers (managers, supervisors, technical workers, clerical/sales workers and production workers) is affected by these workplace practices. Cappelli and Carter (2000) find evidence that HPW practices are associated with higher wages for production workers in manufacturing but their results disappear when controls for human capital are included. In addition, they do not examine how changes in wages might be associated with changes in HPW practices; as a result, their findings may be biased due to unobserved establishment heterogeneity.

Many researchers have argued that computers have had a significant impact on workers wages but this, too, remains a controversial issue. Krueger (1993) found that workers who worked with computers were paid approximately 15 percent more than similar workers who did not work with computers. However, DiNardo and Pischke (1996) found similar effects for workers who used a pencil at work, suggesting perhaps this finding might be driven by omitted variable bias. Doms, Dunne and Troske (1997), using plant-level data on a sub-sample of manufacturing businesses that was matched with micro data on a sample of individuals within each of their establishments, also found a positive relationship between computers and other advanced technologies on the one hand and pay and labor productivity on the other hand. However, this relationship appears somewhat fragile when researchers use longitudinal rather than cross section 
data. In this paper, we will use a measure of the diffusion of computers within an establishment to examine how technology has affected workers wages by occupational class. Since we have both cross section and longitudinal data, we will be able to examine how robust the relationship between computers and wages is.

\section{Workplace Innovation and Wage Inequality}

Theoretically, as discussed in Kremer and Maskin (1996), Acemoglu (1998) and reviewed in Aghion, Caroli and García-Peñalosa (1999), when technological and organizational change take place, skill homogeneity can increase within firms. This would suggest that inequality would decrease within a firm with organizational innovation, even as it rises across firms. However, Aghion et. al. (1999) point out that the outcome is uncertain and in fact there are reasons to think that just the opposite may happen. If firms, as they introduce more organizational practices that have a higher skill component, choose to promote and retrain the low skilled workers within the firm, the inequality in the firm may decline. However, if the firms fire the moderately low-skilled workers (retaining the very low-skilled for menial tasks) and replace them with externally skilled workers (instead of retraining the existing low-skilled workers), inequality within the firm would then increase. As a result, the impact of organizational innovation on inequality within a firm is ambiguous and remains an empirical issue. In addition, if some workers (such as managers and supervisors) are paid a relatively higher premium to engage in HPW practices relative to production workers we may observe increased wage inequality within an establishment. 


\section{Workplace Innovation and Employment Changes}

If technical and organizational change are complementary activities, as argued by Bresnahan et. al. (1999), and given that there is evidence that technical change is skilled biased, this suggests that organizational change may also be skill biased. Osterman (2000) finds that measures of new organizational practices are associated with higher layoff rates of production workers, even within firms that have been experiencing net employment gains. This is suggestive of the reallocation process hypothesized by Kremer and Maskin (1996) and Acemoglu (1998). Caroli and Van Reenen (2001) find evidence for British and French employers that a variety of workplace practices are associated with lower relative demand for unskilled production workers. Therefore, we will examine both the association between HPW practices and total employment changes as well as for production workers alone.

In any analysis of the impact of organizational change on outcomes of interest, it is important to consider who is adopting these practices and how this might affect the interpretation of the results. While there is still relatively little analysis across a representative sample of employers as to who adopts HPW practices, there is some indication in the work by Black, Krivelyova, Lynch (2001), Boning, Ichniowski, Shaw (2001), Bresnahan, Brynjolfsson, Hitt (1999), and Osterman (1994) that there is complementarity between the adoption of information technology and HPW practices. Other factors that appear to be associated with the adoption of HPW practices include the education of the workforce (Black, Krivelyova, Lynch (2001)), the participation of the business in local employer networks (Erikson and Jacoby (2003)), and the financial position of the business. For this last factor the literature is mixed, with work by Nickell, 
Nicolitsas, and Patterson (1996) suggesting that firms that are doing badly are more likely to innovate while others suggesting that, since the innovations are expensive, only those firms that can "afford" financially to do so do. While the empirical analysis below does not explicitly account for characteristics of those who have adopted HPW practices, the question of who adopts clearly affects the final interpretation of our results.

\section{The Data}

The first round of the EQW National Employers Survey was administered by the U.S. Bureau of the Census as a telephone survey in August and September 1994 to a nationally representative sample of more than 3,000 private establishments with more than 20 employees $^{2}$. The survey represents a unique source of information on how employers recruit workers, organize work, invest in physical capital, and utilize education and training investments. The survey over-sampled establishments in the manufacturing sector and establishments with more than 100 employees. Public sector employees, notfor-profit institutions, and corporate headquarters were excluded from the sample. The target respondent in the manufacturing sector was the plant manager and in the nonmanufacturing sector was the local business site manager. However, the survey was designed to allow for multiple respondents so that information could be obtained from establishments that kept financial information such as the book value of capital or the cost of goods and materials used in production at a separate finance office (typically at corporate headquarters for multi-establishment enterprises). The sample frame for the survey was the Bureau of the Census SSEL file, one of the most comprehensive and upto-date listings of establishments in the United States. Although the sampling frame 
omits establishments with less than 20 employees, it captures establishments that employ approximately three-quarters of all workers in the U.S.

The response rate in the first round EQW National Employers Survey for manufacturing establishments was 75 percent. This is substantially higher than most other voluntary establishment surveys. Of the 1,831 manufacturing establishments who participated in the survey, not all respondents completed all parts of the survey by the interview cutoff date of October 1, 1994. Therefore, the final number of manufacturing establishments in the sample for which all parts of the survey were completed was 1,621 . This represents a 66 percent completed survey response rate.

A second survey was administered by the Census Bureau in August $1997^{3}$. There was oversampling of establishments in California, Kentucky, Michigan, Maryland and Pennsylvania and a subsample of establishments that had been contacted in the first round. The final sample of completed interviews for the second round of the EQW-NES included 2,479 manufacturing establishments, representing a 63 percent response rate. A panel of 766 establishments (approximately $2 / 3^{\text {rd }}$ manufacturing and $1 / 3^{\text {rd }}$ nonmanufacturing) can be constructed between the two rounds of the EQW-NES. The panel response rate (for first round manufacturing and non-manufacturing establishments who were contacted and completed the interview in the second round) was 74 percent. However, the second survey was considerably longer in duration than the first survey (close to 45 minutes) and there was a high rate of break-offs mid interview. Therefore, in spite of the high overall response rate there are many businesses that do not provide information on all questions asked including items such as the value of shipments and sales, the book value of the capital stock, wages paid to workers and the proportion of 
workers trained ${ }^{4}$. This significantly reduces the final sample sizes used for analysis in this paper. ${ }^{5}$ In addition, due to limited sampling of non-manufacturing establishments in the EQW longitudinal panel of establishments, we have focused our work just on the manufacturing sector, which has a higher response rate overall.

There are many measures that have been used by various researchers to capture HPW practices. These include job rotation, benchmarking, TQM, profit sharing, teams, employee participation in decision making, indicators of how flat or hierarchical a firm is, employee-supervisor ratios, and workplace training. These measures have been collected as continuous values (such as the percentage of employees meeting regularly to discuss workplace issues) or in binary format (such as whether there is any job rotation or training). While the quality of the EQW data is high as indicated by the high response rate and the fact that the Census Bureau conducted the survey, measurement error could be important, especially when examining changes in practices.

In the empirical work that follows, we estimate both cross section and differenced equations. By estimating a first differenced or fixed effect model we hope to control for any unobserved but time invariant heterogeneity of establishments that may bias our estimates. But while fixed effects estimation may address this bias, if there is measurement error in the data then differencing may amplify measurement error bias that could result in finding no significant effects for the explanatory variables.

For ease of interpretation, we have decided in this paper to proxy for HPW practices (such employees meeting) in a binary fashion rather than as continuous measures. We take continuous measures of the diffusion of HPW practices, such as the proportion of non-managerial workers meeting regularly to discuss workplace issues, and 
recode this into a binary format for ease of interpretation. We recode the variable using the median value in our sample as the cutoff point.

Table 1 presents summary statistics of the workplace practices that we examine in this paper. ${ }^{6}$ Our measure of technology is a binary variable equal to one if more than 30 percent of the workers in the establishment use computers in their work. The first column presents mean values for the 1996 cross section and the next two columns present mean values for the panel subsample that we will use in our fixed effects estimation. In 1996 over 55 percent of establishments had 30 percent or more of their workers using computers and this percentage rose over the period 1993 to 1996.

Other workplace practice measures we use include binary variables equal to one if at least 20 percent of non-managerial workers were in self-managed teams, 50 percent or more of production workers had been trained in the past year, 20 percent or more of workers were involved in job rotation, and 50 percent or more of non-managerial workers met regularly to discuss workplace issues. Looking at the means for the panel sample we see that the diffusion of these practices increased over the 1993-1996 period. The only workplace practice that was used less over this period was profit sharing. This measure is set to one if any group of workers was eligible to participate in profit sharing. Eighty five percent of establishments in the panel had some type of profit sharing in place in 1993 but this had fallen to 61 percent by 1996 . While the panel sample is considerably smaller than the cross section sample, it looks very similar to the cross section except that the panel sample establishments are slightly larger on average and they have lower turnover. 
While employers seemed to have adopted more HPW practices over the 19931996 period, Table 2 shows that there appears to still be a fair amount of switching going on in both directions. While some employers adopted job rotation, others dropped it or used it for a smaller percentage of their workers. For most of our HPW measures, two thirds to three quarters of the establishments did not change their usage of these practices over the 1993-1996 period, with even 55 percent of employers maintaining the same training investment level over this period.

\section{The Empirical Results}

Wages

Do establishments compensate workers for their increased involvement in the production process and for incurring the risk associated with profit sharing forms of compensation? To examine this question, we estimate wage equations using the log of the average establishment hourly wage, first at the establishment level and then by occupation within the establishment, as the dependent variable.

Table 3a presents estimates from cross-section wage equations using the 1996 survey data and for the subsample drawn from the panel data. The dependent variable is the natural logarithm of average hourly wages for workers. We construct the average wage by using information on average hourly wages paid for each of five occupational classes - managers, supervisors, technical staff, production workers, and clerical/sales workers. We then weight these wages by their employment share to construct the establishment average wage. We use this same strategy to construct the average education within the establishment. 
The relationships we observe are quite similar to those we saw when estimating the impact of high performance workplace practices on productivity (Black and Lynch, 2001), which suggests that these establishments do compensate workers for participating in workplace practices that increase productivity under certain circumstances. The results are quite similar across samples. Consistent with the literature using individual level data, higher average education in the establishment is associated with higher average wages; the magnitude suggests that a one year increase in average education raises average hourly wages by $10-13 \%$. Computer use also has a significant impact; establishments with more than $30 \%$ of workers using computers pay $7-10 \%$ more on average. Larger establishments pay higher wages but establishments with more women pay lower wages. Establishments with more turnover also pay lower wages, everthing else constant. ${ }^{7}$

When we examine the impact of HPW practices and measures of employee voice on wages, we find that unionized employers pay about $10 \%$ more than non-unionized businesses. Only when we allow for interactions between unionization status and other workplace practices (Columns 2 and 4), do we see any HPW practices having a significant association with wages. Those unionized establishments with a high proportion of non-managerial workers meeting on a regular basis to discuss workplace issues pay higher average wages. This last finding is consistent with establishment productivity; Black and Lynch (2001) found higher productivity in unionized establishments that had a higher proportion of workers meeting.

In Table $3 b$ we examine the average wage in each establishment by occupation group, where the occupation groups include managers, supervisors, technical workers, 
production workers, and clerical/sales workers. ${ }^{8}$ The results are relatively consistent across occupations; however, there are some notable exceptions. The percentage of workers using computers only matters for the wages of supervisors, clerical, and production workers. Increased training of supervisors raises their wages, but increasing the proportion of workers trained in any of the other occupational categories appears to have no impact on their wages. Supervisors are paid more if they work in unionized establishments. Production workers are also paid more in unionized firms, while clerical and sales workers that are working for unionized firms that have a high proportion of workers involved in regular meetings or have profit sharing also have higher wages.

Since we have information on wages paid in both 1993 and 1996, we are able to examine how changes in worker characteristics and workplace practices are related to changes in wages in the establishment. We do this by estimating a first differenced fixed effects model. In this way we are able to control for any time invariant unobserved heterogeneity in the establishments that might be biasing the estimated coefficients in the cross section results. When we examine the determinants of average hourly wages we find that higher average education in an establishment leads to higher wages; increasing education by one year leads to more than $8 \%$ wage growth. Beyond that though, there is little else of statistical significance. Interestingly, the computer variable is no longer significant suggesting that the significance of the computer variable in Tables $3 a$ and $3 b$ might have been driven by other unobserved qualities of the establishments. ${ }^{9}$

However, as shown in Table 4, when we look at individual occupations we find evidence that employers do appear to compensate at least some of their workers for being more educated or engaging in certain HPW practices. Education has a significant and 
positive relationship to wages for all groups except production workers and supervisors. In addition, increasing the proportion of clerical and sales workers trained over the period 1993-1996 has a positive and significant impact on their wages. Managers in unionized establishments with a high proportion of non-managerial workers meeting regularly in groups are paid a wage premium. Supervisors in establishments with a larger proportion of workers involved in job rotation and self-managed teams are paid a premium as well. While the pay of managers and supervisors is higher when they are working in an establishment with some form of HPW practices, the pay of production workers seems to be unaffected. While this finding may at first glance seem surprising (that managerial workers are being paid a premium to work in establishments where there is more involvement among unskilled workers in the production process), this is consistent with the idea that these practices increase the demands on managers and supervisors as well. Managers and supervisors are now responsible for organizing the production workers and providing an environment conducive to their participation in decision-making. In addition, they must distill the information they receive from lower-level employees, suggesting a need for increased compensation. Finally, this result is also consistent with the supposition that in order to ensure that supervisors do not sabotage efforts to increase participation of production workers in decision making (since this could undermine their own authority) a wage premium must be paid. There still may be other time-varying unobserved characteristics of establishments, such as changes in managerial quality, which might be biasing these estimates. However, these findings are suggestive of a premium being paid to non-production workers relative to production workers to work in a HPW environment. 


\section{Wage Inequality and Workplace Innovation}

To see how technological and organizational change has affected relative wages, we focus on the ratio of the average wage of non-production workers in an establishment to the average wage of production workers in an establishment, where non-production workers include managers, supervisors, technical and professional workers, and sales and clerical workers. This is the standard grouping of workers by skill that is used in surveys such as the Census Bureau's Annual Survey of Manufacturers. ${ }^{10}$ Explanatory variables include measures of relative human capital (the ratio of average education of nonproduction workers to production workers average education and the ratio of the proportion of non-production workers trained to the proportion of production workers trained), our measure of information technology (an indicator if more than $30 \%$ of all workers use computers), our vector of organizational variables, and demographic characteristics of the establishment. Again, failure to address unobserved heterogeneity may bias our empirical results so we estimate the relative wage equation in both levels (using data from 1996) and first differenced (using data from 1993 and 1996 panel) in order to remove the time invariant fixed effects. These results are reported in Tables 5 and 6.

Table 5 presents findings on the determinants of the ratio of nonproduction to production worker hourly wages using the 1996 cross section. Column 1 presents our basic model of human capital, organization, and technology variables, while Column 2 includes interactions between unionization and workplace practices. Columns 3 and 4 show the results when we do not include individual practices but instead use an index: in Column 3, we use a count of the workplace practices (which ranges from zero to five, 
depending on the number an individual plant has implemented) and Column 4 uses an index of workplace practices. ${ }^{11}$ These results suggest that technology and worker characteristics have a significant impact on wage inequality within an establishment; computer diffusion reduces inequality, while increased disparity in the education of nonproduction workers relative to production workers increases it. More women and minorities are associated with higher inequality, as is higher turnover. Large firms have less wage inequality, ceteris paribus.

Among the workplace practices, we find little of statistical significance in the cross section results. Profit sharing appears to reduce inequality in non-unionized firms but slightly increases it in unionized firms. However, the findings change when we reestimate this inequality measure in a fixed effects model over the period of 1993-1996. As shown in Table 6, with the exception of the relative education variable, other worker characteristics and computer use become insignificant. The collapse of the computer variable in the fixed effects estimation is similar to what happened in the wage equations.

Interestingly, we again see that, controlling for time-invariant establishment characteristics, introducing workplace practices increases relative wage inequality. The presence of significant job rotation increases wage inequality, as does profit sharing in unionized establishments. Both the count measure and the index of workplace practices suggest that these high performance workplace practices actually increase withinestablishment inequality. This is consistent with the wage results of Table 4 where it appeared that non-production workers such as managers and supervisors were paid wage premiums to work in HPW businesses while production workers did not receive a similar premium. 


\section{Workplace Innovation and Employment Changes}

A final outcome we examine is whether high performance workplace practices have an impact on large-scale employment reductions within establishments. To do this, we look at the impact of 1993 workplace practices and establishment characteristics on an indicator variable equal to one if the establishment has undergone substantial reduction in the number of employees by 1996 . We use $5 \%$ and $20 \%$ as cutoffs and look at total employment and then production worker employment. Table 7 presents these results.

Over forty percent of the establishments in our sample experienced a net employment reduction of 5 percent or more and almost twenty percent experienced a net reduction of 20 percent or more. If we concentrate on this latter category of large layoffs, we see that the establishments most likely to undergo such a large net reduction in employment by 1996 were large employers, had high turnover and were part of multiestablishment firms in 1993. In terms of the relationship between HPW practices and large layoffs, we see a mixed picture. Those establishments that had a high proportion of workers in self-managed teams or that had profit sharing in 1993 were more likely to undergo a larger reduction in net employment. But those establishments that had a high proportion of workers in job rotation or that were unionized with a high proportion of non-managerial workers meeting regularly to discuss workplace issues were less likely to have experienced such large net employment reductions.

When we examine only production workers, we again see that larger and multiestablishments were more likely to reduce production worker employment by 20 percent or more over the 1993-1996 period. But those establishments that had a higher 
proportion of workers using computers or higher average education in 1993 were less likely to have experienced such large drops in production worker employment. As with overall employment, those establishments with a higher proportion of workers in selfmanaged teams in 1993 were more likely to have laid off a significant proportion of production workers by 1996, except if they were unionized establishments. While this analysis is primarily descriptive in nature it does suggest that while some HPW practices do seem to be associated with employment reduction as Osterman (2000) found, this does seem to vary by practice and whether or not the establishment with the HPW practice is unionized.

\section{Conclusions}

During the period 1993-1996 U.S. manufacturing employers have been actively engaged in workplace re-organization, and these changes in workplace practices have played a significant role in the recent rise in manufacturing productivity. While manufacturing firms are enjoying the benefits of these technological and managerial innovations, some workers appear to also be sharing some of these gains in the form of higher wages. Though these results may be affected by data quality issues, we find that these gains do not seem to be evenly distributed within establishments. Non-production workers working in HPW environments appear to be paid a wage premium while production workers' pay seems unaffected. Perhaps, then, it is not surprising to find that these same HPW practices appear to increase with-establishment wage inequality. Finally, the association between HPW practices and large net reductions in employment seems to be a mixed picture, with some practices, such as self-managed teams, associated 
with greater employment reductions while other practices, such as the percentage of workers involved in job rotation, associated with lower employment reductions. More generally, our empirical work suggests that there are significant differences between unionized and non- unionized employers in the impact of organizational change on all three of the outcome measures examined in this paper. 


\section{REFERENCES}

Acemoglu, Daron. 1998. "Changes in Unemployment and Wage Inequality: An Alternative Theory and Some Evidence," Working Paper 6658. Cambridge, MA: National Bureau of Economic Research.

Aghion, Philippe, Eve Caroli and C. Garcia-Penalosa. "Inequality and Economic Growth: The Perspective of the New Growth Theory," Journal of Economic Literature, forthcoming.

Arthur, Jeffrey. 1994. "Effects of Human Resource Systems on Manufacturing Performance and Turnover," Academy of Management Review, vol. 37, pp. 670-87.

Autor, David, Lawrence F. Katz and Alan B. Krueger. 1998. "Computing Inequality: Have Computers Changed the Labor Market?” Quarterly Journal of Economics, vol. 113, no. 4, pp. 1169-1213.

Bailey, Thomas. 1993. "Organizational Innovation in the Apparel Industry", Industrial Relations, vol. 32, pp. 30-48.

Batt, Rosemary. 1995. "Performance and Welfare Effects of Work Restructuring: Evidence from Telecommunications Services." Ph.D. Dissertation, MIT Sloan School of Management.

Berg, Peter, Eileen Appelbaum, Thomas Bailey, and Arne Kallenberg. 1996. "The Performance Effects of Modular Production in the Apparel Industry", Industrial Relations, vol. 35, pp. 356-373.

Berman, Eli, John Bound and Zvi Griliches. 1994. "Changes in the Demand for Skilled Labor Within U.S. Manufacturing: Evidence from the Annual Survey of Manufactures," Quarterly Journal of Economics, May, pp. 367-397.

Black, Sandra E. and Lisa M. Lynch. 2001. "How to Compete: "The Impact of Workplace Practices and Information Technology on Productivity," Review of Economics and Statistics, August.

American Economic Review, May. . 1996. "Human Capital Investments and Productivity," . 2000. "What's Driving the New Economy: The Benefits of Workplace Innovation,” NBER working paper number 7479, January.

and Anya Krivelyova. 2001. "Restructuring the Workplace and Changing Skill Demands", mimeo, Tufts University, July. 
Boning, Brent, Casey Ichniowski and Kathryn Shaw. 2001. "Opportunity Counts: Teams and the Effectiveness of Production Incentives," Working Paper No. 8306. Cambridge, MA: National Bureau of Economic Research.

Bresnahan, Timothy, Eric Brynjolfsson and Lorin Hitt. 1999. "Information Technology Workplace Organization, and the Demand for Skilled Labor: Firm-Level Evidence." Working Paper No. 7136. Cambridge, MA: National Bureau of Economic Research.

Cappelli, Peter and William Carter. 2000. "Computers, Work Organization, and Wage Outcomes." Working Paper No. 7987. Cambridge, MA: National Bureau of Economic Research.

Caroli, Eve and John Van Reenen. 2001. "Organization, Skills and Technology: Evidence from a Panel of British and French Establishments.” Quarterly Journal of Economics, vol. 116, pp. 1449-1492.

Chennells, Lucy and John Van Reenan. 1999. "Has Technology Hurt Less Skilled Workers?: An Econometric Survey of the Effects of Technical Changes on the Structure of Pay and Jobs." Institute of Fiscal Studies working paper W99/27, London, England.

DiNardo, John and Jorn-Steffan Pischke, 1996, "The Returns to Computers Revisited: Have Pencils Changed the Wage Structure Too?" Working Paper No. 5606. Cambridge, MA: National Bureau of Economic Research.

Doms, Mark, Dunne, Timothy, and Troske, Kenneth. 1997. "Workers, Wages and Technology." Quarterly Journal of Economics, vol. 112, Feb., pp. 235-290.

Dunlop, John and David Weil, "Diffusion and Performance of Modular Production in the U.S. Apparel Industry.” Industrial Relations, vol. 35, pp.334-354.

Dunne, Timothy, Lucia Foster, John Haltiwanger and Kenneth Troske. 2000. Wage and Productivity Dispersion in U.S. Manufacturing: The Role of Computer Investment." Working Paper No. 7465. Cambridge, MA: National Bureau of Economic Research.

Erikson, Christopher L. and Sanford M. Jacoby. 2003. "Management Matters: Employers Networks and Human Resource Innovations." Industrial and Labor Relations Review, vol. 56 no. 2, January.

Hall, C., J. Rosenthal, and J. Wade. 1993. "How to Make Reengineering Really Work." Harvard Business Review, November.

Hammer, Michael. 1990. "Reengineering Work: Don't Automate, Obliterate." Harvard Business Review, July.

Huselid, Mark. 1995. “The Impact of Human Resource Management Practices on Turnover, Productivity, and Corporate Financial Performance.” Academy of Management Journal, vol. 38, pp. 635-672. 
Ichniowski, Casey. 1990. "Human Resource Management Systems and the Performance of U.S. Manufacturing Businesses." Working Paper No. 3449. Cambridge, MA: National Bureau of Economic Research.

, Kathryn Shaw, and Gabriella Prennushi. 1997. "The Effects of Human Resource Management on Productivity." American Economic Review, vol. 87, pp. 29131 .

Kandel, E. and Edward Lazear. 1992. "Peer Pressure and Partnerships.” Journal of Political Economy, Vol. 100, pp. 801-817.

Kelley, Mary Ellen. 1996. "Participative Bureaucracy and Productivity in the Machine Products Sector.” Industrial Relations, vol. 35 ,pp. 374-399.

Krafcik, John. 1988. "Triumph of the Lean Production System.” Sloan Management

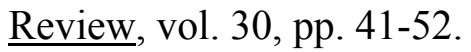

Kremer, Michael and Eric Maskin. 1996. "Wage Inequality and Segregation by Skill." Working Paper No. 5718. Cambridge, MA: National Bureau of Economic Research.

Krueger, Alan. 1993. "How Computers Have Changed the Wage Structure: Evidence from Micro Data, 1984-1989." Quarterly Journal of Economics, Feb. pp.33-60.

Lynch, Lisa M. and Sandra E. Black. 1998. "Beyond the Incidence of Employer Provided Training.” Industrial and Labor Relations Review, October.

Machin, Steve and John Van Reenan (1998). "Technology and Changes in Skill Structure: Evidence from Seven OECD Countries." Berkeley Center for Labor Economics Working Paper No. 3.

Milgrom, Paul and J. Roberts. 1995. "Complementarities and Fit: Structure and Organizational Change in Manufacturing." Journal of Accounting and Economics, vol. 19, pp. 179-208.

Nickell, Steve, Daphne Nicolitsas and Malcom Patterson. 1996. "Does Doing Badly Encourage Management Innovation?” Oxford Institute for Economics and Statistics Working Paper, August.

Osterman, Paul. 1994. "How Common is Workplace Transformation and Who Adopts It?” Industrial and Labor Relations Review, vol. 47., no. 2, pp. 175-88.

. 2000. "Work Reorganization in an Era of Restructuring: Trends in Diffusion and Effects on Employee Welfare." Industrial and Labor Relations Review, Vol. 53, no. 2, pp.179-196. 
Womack, James, Daniel Jones, and Daniel Roos. 1991. The Machine that Changed the World. New York, NY: Rawson/Macmillan. 
Table 1: Summary Statistics

\begin{tabular}{|c|c|c|c|}
\hline Variable Name & 1996-Full Sample & 1993 Panel & 1996 Panel \\
\hline Log(Average Wage) & $\begin{array}{c}2.6 \\
(.29)\end{array}$ & $\begin{array}{l}2.29 \\
(.31)\end{array}$ & $\begin{array}{l}2.29 \\
(.29)\end{array}$ \\
\hline Total number of workers & $\begin{array}{c}540 \\
(816)\end{array}$ & $\begin{array}{c}657 \\
(967)\end{array}$ & $\begin{array}{c}611 \\
(738)\end{array}$ \\
\hline Average Education & $\begin{array}{l}12.5 \\
(.93)\end{array}$ & $\begin{array}{l}12.6 \\
(1.0)\end{array}$ & $\begin{array}{l}12.5 \\
(.93)\end{array}$ \\
\hline Turnover (proportion $<1$ year) & $\begin{array}{l}13.7 \\
(14.1)\end{array}$ & $\begin{array}{c}13.5 \\
(14.0)\end{array}$ & $\begin{array}{c}12.6 \\
(13.6)\end{array}$ \\
\hline \% Women & $\begin{array}{c}34 \\
(20)\end{array}$ & $\begin{array}{c}32 \\
(22)\end{array}$ & $\begin{array}{c}34 \\
(21)\end{array}$ \\
\hline$\%$ Minority & $\begin{array}{l}27 \\
(25)\end{array}$ & $\begin{array}{l}25 \\
(24)\end{array}$ & $\begin{array}{c}28 \\
(25)\end{array}$ \\
\hline $\begin{array}{l}>20 \% \text { of Non-Managerial Workers in } \\
\text { Self-Managed Teams }\end{array}$ & $\begin{array}{c}.25 \\
(.43)\end{array}$ & $\begin{array}{c}.20 \\
(.40)\end{array}$ & $\begin{array}{l}.25 \\
(.43)\end{array}$ \\
\hline$>50 \%$ of Production Workers Trained & $\begin{array}{l}.61 \\
(.49)\end{array}$ & $\begin{array}{l}.59 \\
(.49)\end{array}$ & $\begin{array}{l}.63 \\
(.48)\end{array}$ \\
\hline Profit sharing & $\begin{array}{l}.60 \\
(.49)\end{array}$ & $\begin{array}{l}.85 \\
(.36)\end{array}$ & $\begin{array}{l}.61 \\
(.49)\end{array}$ \\
\hline $\begin{array}{l}>20 \% \text { of Non-Managerial Workers } \\
\text { Involved in Job Rotation }\end{array}$ & $\begin{array}{c}.40 \\
(.49)\end{array}$ & $\begin{array}{c}.34 \\
(.47)\end{array}$ & $\begin{array}{c}.38 \\
(.49)\end{array}$ \\
\hline Unionized & $\begin{array}{l}.35 \\
(.48)\end{array}$ & $\begin{array}{l}.37 \\
(.47)\end{array}$ & $\begin{array}{l}.38 \\
(.48)\end{array}$ \\
\hline $\begin{array}{l}>50 \% \text { of Non-Managerial Workers } \\
\text { Meeting Regularly in Groups }\end{array}$ & $\begin{array}{l}.56 \\
(.50)\end{array}$ & $\begin{array}{l}.52 \\
(.50)\end{array}$ & $\begin{array}{l}.64 \\
(.48)\end{array}$ \\
\hline $\begin{array}{l}>30 \% \text { of All Workers using } \\
\text { Computers }\end{array}$ & $\begin{array}{l}.55 \\
(.50)\end{array}$ & $\begin{array}{c}.50 \\
(.50)\end{array}$ & $\begin{array}{l}.57 \\
(.50)\end{array}$ \\
\hline Number of observations & 524 & 183 & 183 \\
\hline
\end{tabular}


Table 2: Changes in Organizational Structure (Panel Data)

\begin{tabular}{|c|c|c|c|}
\hline & $\begin{array}{l}\text { \% Increased } \\
\text { (Moved into } \\
\text { Group) }\end{array}$ & $\begin{array}{l}\text { \% Decreased } \\
\text { (Moved out of } \\
\text { Group) }\end{array}$ & $\begin{array}{c}\text { \% Stayed the } \\
\text { Same }\end{array}$ \\
\hline $\begin{array}{l}>20 \% \text { of Non-Managerial } \\
\text { Workers in Self-Managed } \\
\text { Teams }\end{array}$ & 15 & 10 & 75 \\
\hline Profit sharing & 4 & 28 & 68 \\
\hline $\begin{array}{l}>20 \% \text { of Non-Managerial } \\
\text { Workers involved in Job } \\
\text { Rotation }\end{array}$ & 16 & 12 & 72 \\
\hline $\begin{array}{l}>30 \% \text { of Workers using } \\
\text { Computers }\end{array}$ & 17 & 11 & 72 \\
\hline $\begin{array}{l}>50 \% \text { of Non-Managerial } \\
\text { Workers Meeting Regularly } \\
\text { in Groups }\end{array}$ & 21 & 9 & 69 \\
\hline $\begin{array}{l}>50 \% \text { of Production } \\
\text { Workers Trained }\end{array}$ & 24 & 21 & 55 \\
\hline
\end{tabular}

Note: Unless otherwise noted, variables refer to all workers in the establishment. 
Table 3a

Wage Equations All Workers 1996 Cross Section

\begin{tabular}{cccc}
$\begin{array}{c}\text { No interactions } \\
\text { Full sample }\end{array}$ & $\begin{array}{c}\text { Interaction } \\
\text { Full sample }\end{array}$ & $\begin{array}{c}\text { No interactions } \\
\text { Panel sample }\end{array}$ & $\begin{array}{c}\text { Interactions } \\
\text { Panel sample }\end{array}$ \\
\hline & & &
\end{tabular}

\begin{tabular}{|c|c|c|c|c|}
\hline \multicolumn{5}{|c|}{ Worker Characteristics } \\
\hline Average Education & $\begin{array}{l}.10^{*} \\
(.01)\end{array}$ & $\begin{array}{l}.10^{*} \\
(.01)\end{array}$ & $\begin{array}{l}.136^{*} \\
(.020)\end{array}$ & $\begin{array}{l}.136^{*} \\
(.019)\end{array}$ \\
\hline \multirow[t]{2}{*}{$>50 \%$ Production Workers Trained } & .002 & .004 & $.054 *$ & $.064^{*}$ \\
\hline & $(.02)$ & $(.02)$ & $(.033)$ & $(.034)$ \\
\hline \multirow[t]{2}{*}{ Turnover (proportion $<1$ year) } & $-.003 *$ & $-.003^{*}$ & $-.004 *$ & $-.004 *$ \\
\hline & $(.001)$ & $(.001)$ & $(.002)$ & $(.002)$ \\
\hline \multirow{2}{*}{ \% Women } & $-.004 *$ & $-.004 *$ & $-.004 *$ & $-.005^{*}$ \\
\hline & $(.001)$ & $(.001)$ & $(.001)$ & $(.001)$ \\
\hline \multirow[t]{2}{*}{$\%$ Minority } & .0004 & .0004 & .0002 & .0002 \\
\hline & $(.0004)$ & $(.0004)$ & $(.0006)$ & $(.0006)$ \\
\hline \multirow[t]{2}{*}{ Total Workers } & $.00004 *$ & $.00004 *$ & $.00005^{*}$ & $.00005^{*}$ \\
\hline & $(.00001)$ & $(.00001)$ & $(.00001)$ & $(.00001)$ \\
\hline \multirow[t]{2}{*}{ Multiple establishment } & $\begin{array}{l}-.017 \\
(.024)\end{array}$ & $\begin{array}{l}-.015 \\
(.023)\end{array}$ & & \\
\hline & Tech & & & \\
\hline \multirow{2}{*}{$\begin{array}{l}>30 \% \text { of Total Workers using } \\
\text { Computers }\end{array}$} & $.10^{*}$ & $.09^{*}$ & $.077 *$ & $.073 *$ \\
\hline & $(.02)$ & $(.02)$ & $(.036)$ & $(.035)$ \\
\hline \multicolumn{5}{|c|}{ High Performance Work Systems } \\
\hline$>\mathbf{2 0} \%$ of Non-Managerial Workers & -.01 & .01 & .01 & .03 \\
\hline in Self-Managed Teams & $(.02)$ & $(.03)$ & $(.04)$ & $(.05)$ \\
\hline \multirow[t]{2}{*}{ Profit sharing } & .03 & .03 & .02 & .04 \\
\hline & $(.02)$ & $(.02)$ & $(.03)$ & $(.04)$ \\
\hline \multirow{3}{*}{$\begin{array}{l}>20 \% \text { of Non-Managerial Workers } \\
\text { involved in Job Rotation }\end{array}$} & -.01 & -.01 & -.03 & -.032 \\
\hline & $(.02)$ & $(.02)$ & $(.03)$ & $(.03)$ \\
\hline & Emplo & & & \\
\hline \multirow{2}{*}{ Unionized } & $.09 *$ & .03 & $.08 *$ & .04 \\
\hline & $(.02)$ & $(.04)$ & $(.02)$ & $(.06)$ \\
\hline \multirow{3}{*}{$\begin{array}{l}>50 \% \text { of Non-Managerial Workers } \\
\text { Meeting Regularly in Groups }\end{array}$} & .03 & -.01 & .015 & -.31 \\
\hline & $(.02)$ & $(.02)$ & $(.03)$ & $(.04)$ \\
\hline & Interact & ms & & \\
\hline Union*Profit Sharing & . & $\begin{array}{c}.02 \\
(.04)\end{array}$ & - & $\begin{array}{l}-.069 \\
(.057)\end{array}$ \\
\hline \multirow{4}{*}{$\begin{array}{l}\text { Union*>50\% of Non-Managerial } \\
\text { Workers Meeting Regularly in } \\
\text { Groups } \\
\text { Union*>20\% of Non-Managerial } \\
\text { Workers in Self-Managed Teams }\end{array}$} & - & $.10^{*}$ & - & $.16^{*}$ \\
\hline & & $(.04)$ & & $(.06)$ \\
\hline & - & -.03 & - & -.078 \\
\hline & & $(.05)$ & & $(.073)$ \\
\hline Adjusted R-Square & .4803 & .4841 & .6089 & .6221 \\
\hline Number of observations & 524 & 524 & 183 & 183 \\
\hline
\end{tabular}

Note: Unless otherwise noted, variables refer to all workers in the establishment. Unionized $=1$ if an establishment answered yes to the question "Is your establishment represented by a union or unions?" Standard Errors in ()$,{ }^{*}$ denotes significant at the $10 \%$ level. All estimation has been done using the HuberWhite estimator of variance to correct standard errors. All equations also include two-digit industry dummies. 
Table 3b

Wage Equations by Occupation 1996 Cross Section

\begin{tabular}{|c|c|c|c|c|c|}
\hline Variable Name & Managers & Supervisors & $\begin{array}{l}\text { Technical } \\
\text { Workers }\end{array}$ & $\begin{array}{l}\text { Production } \\
\text { Workers }\end{array}$ & $\begin{array}{c}\text { Clerical/Sales } \\
\text { Workers }\end{array}$ \\
\hline \multicolumn{6}{|c|}{ Worker Characteristics } \\
\hline Average Education & $\begin{array}{l}.05^{*} \\
(.01)\end{array}$ & $\begin{array}{c}.02 \\
(.01)\end{array}$ & $\begin{array}{l}.06^{*} \\
(.01)\end{array}$ & $\begin{array}{l}.04 * \\
(.01)\end{array}$ & $\begin{array}{l}.04 * \\
(.01)\end{array}$ \\
\hline$\%$ Trained in Occupation & $\begin{array}{l}.0006 \\
(.0005)\end{array}$ & $\begin{array}{l}.0008^{*} \\
(.0003)\end{array}$ & $\begin{array}{l}-.0001 \\
(.0003)\end{array}$ & $\begin{array}{l}.0002 \\
(.0002)\end{array}$ & $\begin{array}{l}.00002 \\
(.00003)\end{array}$ \\
\hline Turnover (proportion $<1$ year) & $\begin{array}{l}.0001 \\
(.001)\end{array}$ & $\begin{array}{l}-.001 \\
(.001)\end{array}$ & $\begin{array}{l}-.002 * \\
(.001)\end{array}$ & $\begin{array}{l}-.004^{*} \\
(.001)\end{array}$ & $\begin{array}{l}-.003^{*} \\
(.001)\end{array}$ \\
\hline \% Women & $\begin{array}{l}-.002 * \\
(.001)\end{array}$ & $\begin{aligned}-.003 * \\
(.001)\end{aligned}$ & $\begin{array}{r}-.003 * \\
(.001)\end{array}$ & $\begin{array}{l}-.005^{*} \\
(.001)\end{array}$ & $\begin{array}{l}-.003 * \\
(.001)\end{array}$ \\
\hline \% Minority & $\begin{array}{l}.002 * \\
(.001)\end{array}$ & $\begin{array}{l}.001^{*} \\
(.0004)\end{array}$ & $\begin{array}{l}.001^{*} \\
(.0004)\end{array}$ & $\begin{array}{l}-.0006 \\
(.0004)\end{array}$ & $\begin{array}{l}.001^{*} \\
(.0004)\end{array}$ \\
\hline Total Workers & $\begin{array}{l}.00002 \\
(.00002)\end{array}$ & $\begin{array}{l}.00003^{*} \\
(.00001)\end{array}$ & $\begin{array}{l}.00002 \\
(.00001)\end{array}$ & $\begin{array}{l}.00006^{*} \\
(.00001)\end{array}$ & $\begin{array}{l}.00001 \\
(.00001)\end{array}$ \\
\hline Multiple establishment & $\begin{array}{l}-.06^{*} \\
(.036)\end{array}$ & $\begin{array}{l}-.015 \\
(.025)\end{array}$ & $\begin{array}{l}-.04 \\
(.028)\end{array}$ & $\begin{array}{l}.027 \\
(.024)\end{array}$ & $\begin{array}{l}-.009 \\
(.03)\end{array}$ \\
\hline \multicolumn{6}{|c|}{ Technology } \\
\hline $\begin{array}{l}>30 \% \text { of Total Workers using } \\
\text { Computers }\end{array}$ & $\begin{array}{l}.03 \\
(.03)\end{array}$ & $\begin{array}{l}.04^{*} \\
(.02)\end{array}$ & $\begin{array}{c}.04 \\
(.025)\end{array}$ & $\begin{array}{l}.10^{*} \\
(.02)\end{array}$ & $\begin{array}{l}.05^{*} \\
(.02)\end{array}$ \\
\hline \multicolumn{6}{|c|}{ High Performance Work Systems } \\
\hline $\begin{array}{l}>20 \% \text { of Non-Managerial Workers } \\
\text { in Self-Managed Teams }\end{array}$ & $\begin{array}{l}.04 \\
(.04)\end{array}$ & $\begin{array}{l}-.02 \\
(.03)\end{array}$ & $\begin{array}{l}-.03 \\
(.03)\end{array}$ & $\begin{array}{l}.03 \\
(.03)\end{array}$ & $\begin{array}{l}-.04 \\
(.03)\end{array}$ \\
\hline Profit sharing & $\begin{array}{l}-.003 \\
(.04)\end{array}$ & $\begin{array}{l}.05^{*} \\
(.026)\end{array}$ & $\begin{array}{l}.02 \\
(.03)\end{array}$ & $\begin{array}{l}.03 \\
(.02)\end{array}$ & $\begin{array}{l}.03 \\
(.03)\end{array}$ \\
\hline $\begin{array}{l}>20 \% \text { of Non-Managerial Workers } \\
\text { involved in Job Rotation }\end{array}$ & $\begin{array}{l}.03 \\
(.03)\end{array}$ & $\begin{array}{l}.02 \\
(.02)\end{array}$ & $\begin{array}{l}-.01 \\
(.02)\end{array}$ & $\begin{array}{l}-.02 \\
(.02)\end{array}$ & $\begin{array}{l}.03 \\
(.02)\end{array}$ \\
\hline \multicolumn{6}{|c|}{ Employee Voice } \\
\hline Unionized & $\begin{array}{l}.04 \\
(.06)\end{array}$ & $\begin{array}{l}.08^{*} \\
(.04)\end{array}$ & $\begin{array}{l}.04 \\
(.05)\end{array}$ & $\begin{array}{l}.09 * \\
(.04)\end{array}$ & $\begin{array}{l}-.06 \\
(.05)\end{array}$ \\
\hline $\begin{array}{l}>50 \% \text { of Non-Managerial Workers } \\
\text { Meeting Regularly in Groups }\end{array}$ & $\begin{array}{l}-.05 \\
(.04)\end{array}$ & $\begin{array}{l}-.01 \\
(.03)\end{array}$ & $\begin{array}{l}-.003 \\
(.03)\end{array}$ & $\begin{array}{l}.01 \\
(.02)\end{array}$ & $\begin{array}{l}-.02 \\
(.03)\end{array}$ \\
\hline \multicolumn{6}{|c|}{ Interaction Terms } \\
\hline Union*Profit Sharing & $\begin{array}{l}.06 \\
(.06)\end{array}$ & $\begin{array}{l}-.01 \\
(.04)\end{array}$ & $\begin{array}{l}-.01 \\
(.05)\end{array}$ & $\begin{array}{l}-.02 \\
(.04)\end{array}$ & $\begin{array}{l}.09 * \\
(.05)\end{array}$ \\
\hline $\begin{array}{l}\text { Union* }>50 \% \text { of Non-Managerial } \\
\text { Workers Meeting Regularly in } \\
\text { Groups }\end{array}$ & $\begin{array}{l}.08 \\
(.06)\end{array}$ & $\begin{array}{l}.05 \\
(.04)\end{array}$ & $\begin{array}{l}.07 \\
(.05)\end{array}$ & $\begin{array}{l}.09 \\
(.04)\end{array}$ & $\begin{array}{l}.12^{*} \\
(.05)\end{array}$ \\
\hline $\begin{array}{l}\text { Union*>20\% of Non-Managerial } \\
\text { Workers in Self-Managed Teams }\end{array}$ & $\begin{array}{l}-.09 \\
(.08)\end{array}$ & $\begin{array}{c}-.02 \\
(.05)\end{array}$ & $\begin{array}{c}.04 \\
(.05)\end{array}$ & $\begin{array}{c}-.04 \\
(.05)\end{array}$ & $\begin{array}{l}.002 \\
(.05)\end{array}$ \\
\hline Adjusted R-Square & .1401 & .2774 & .2428 & .4611 & .1719 \\
\hline Number of observations & 469 & 520 & 501 & 590 & 556 \\
\hline
\end{tabular}

Note: Unless otherwise noted, variables refer to all workers in the establishment. Unionized $=1$ if an establishment answered yes to the question "Is your establishment represented by a union or unions?" Standard Errors in ()$,{ }^{*}$ denotes significant at the $10 \%$ level. All estimation has been done using the HuberWhite estimator of variance to correct standard errors. All equations also include two-digit industry dummies. 
Table 4:

Wage Equation

Establishment Fixed Effects

\begin{tabular}{|c|c|c|c|c|c|}
\hline Variable Name & Managers & Supervisors & $\begin{array}{l}\text { Technical } \\
\text { Workers }\end{array}$ & $\begin{array}{l}\text { Production } \\
\text { Workers }\end{array}$ & $\begin{array}{c}\text { Clerical/Sales } \\
\text { Workers }\end{array}$ \\
\hline \multicolumn{6}{|c|}{ Worker Characteristics } \\
\hline Average Education & $\begin{array}{l}.04 * \\
(.02)\end{array}$ & $\begin{array}{l}-.005 \\
(.009)\end{array}$ & $\begin{array}{l}.03 * \\
(.01)\end{array}$ & $\begin{array}{l}.003 \\
(.018)\end{array}$ & $\begin{array}{l}.04 * \\
(.01)\end{array}$ \\
\hline$\%$ Trained in Occupation & $\begin{array}{l}.0008 \\
(.0005)\end{array}$ & $\begin{array}{l}.0001 \\
(.0003)\end{array}$ & $\begin{array}{c}.0002 \\
(.0004)\end{array}$ & $\begin{array}{l}-.0002 \\
(.0003)\end{array}$ & $\begin{array}{l}.0007^{*} \\
(.0003)\end{array}$ \\
\hline Turnover (proportion $<1$ year) & $\begin{array}{l}.0017 \\
(.0013)\end{array}$ & $\begin{array}{l}.001 \\
(.001)\end{array}$ & $\begin{array}{l}-.001 \\
(.001)\end{array}$ & $\begin{array}{l}-.001 \\
(.001)\end{array}$ & $\begin{array}{l}-.0004 \\
(.001)\end{array}$ \\
\hline \% Women & $\begin{array}{l}.003^{*} \\
(.002)\end{array}$ & $\begin{array}{l}-.0004 \\
(.0013)\end{array}$ & $\begin{array}{l}.004 * \\
(.002)\end{array}$ & $\begin{array}{l}.001 \\
(.001)\end{array}$ & $\begin{array}{l}.001 \\
(.001)\end{array}$ \\
\hline$\%$ Minority & $\begin{array}{l}-.001 \\
(.002)\end{array}$ & $\begin{array}{l}.001 \\
(.001)\end{array}$ & $\begin{array}{l}.002 \\
(.002)\end{array}$ & $\begin{array}{l}-.002 * \\
(.001)\end{array}$ & $\begin{array}{l}-.0017 \\
(.0012)\end{array}$ \\
\hline Total Workers & $\begin{array}{l}.0000 \\
(.0000)\end{array}$ & $\begin{array}{l}.00003^{*} \\
(.00001)\end{array}$ & $\begin{array}{l}.00004^{*} \\
(.00002)\end{array}$ & $\begin{array}{l}.0000 \\
(.0000)\end{array}$ & $\begin{array}{l}.0000 \\
(.0000)\end{array}$ \\
\hline \multicolumn{6}{|c|}{ Technology } \\
\hline $\begin{array}{l}>30 \% \text { of Total Workers using } \\
\text { Computers }\end{array}$ & $\begin{array}{l}-.02 \\
(.04)\end{array}$ & $\begin{array}{c}.01 \\
(.03)\end{array}$ & $\begin{array}{l}-.03 \\
(.04)\end{array}$ & $\begin{array}{c}.02 \\
(.03)\end{array}$ & $\begin{array}{l}.03 \\
(.03)\end{array}$ \\
\hline \multicolumn{6}{|c|}{ High Performance Work Systems } \\
\hline $\begin{array}{l}>\mathbf{2 0} \% \text { of Non-Managerial Workers } \\
\text { in Self-Managed Teams }\end{array}$ & $\begin{array}{l}-.04 \\
(.05)\end{array}$ & $\begin{array}{l}-.06 \\
(.04)\end{array}$ & $\begin{array}{l}-.04 \\
(.05)\end{array}$ & $\begin{array}{l}-.02 \\
(.03)\end{array}$ & $\begin{array}{l}.09^{*} \\
(.04)\end{array}$ \\
\hline Profit sharing & $\begin{array}{l}-.03 \\
(.05)\end{array}$ & $\begin{array}{l}-.03 \\
(.03)\end{array}$ & $\begin{array}{l}-.05 \\
(.05)\end{array}$ & $\begin{array}{l}-.004 \\
(.03)\end{array}$ & $\begin{array}{l}-.08^{*} \\
(.04)\end{array}$ \\
\hline $\begin{array}{l}>20 \% \text { of Non-Managerial Workers } \\
\text { involved in Job Rotation }\end{array}$ & $\begin{array}{l}.01 \\
(.04)\end{array}$ & $\begin{array}{l}.07^{*} \\
(.03)\end{array}$ & $\begin{array}{l}-.05 \\
(.04)\end{array}$ & $\begin{array}{l}-.02 \\
(.03)\end{array}$ & $\begin{array}{l}.01 \\
(.03)\end{array}$ \\
\hline \multicolumn{6}{|c|}{ Employee Voice } \\
\hline Unionized & $\begin{array}{l}-.02 \\
(.18)\end{array}$ & $\begin{array}{l}-.02 \\
(.11)\end{array}$ & $\begin{array}{l}-.06 \\
(.17)\end{array}$ & $\begin{array}{l}-.11 \\
(.11)\end{array}$ & $\begin{array}{l}.23 \\
(.14)\end{array}$ \\
\hline $\begin{array}{l}>50 \% \text { of Non-Managerial Workers } \\
\text { Meeting Regularly in Groups }\end{array}$ & $\begin{array}{l}-.03 \\
(.05)\end{array}$ & $\begin{array}{l}.03 \\
(.03)\end{array}$ & $\begin{array}{l}.03 \\
(.05)\end{array}$ & $\begin{array}{r}-.002 \\
(.03)\end{array}$ & $\begin{array}{l}.06 \\
(.04)\end{array}$ \\
\hline \multicolumn{6}{|c|}{ Interaction Terms } \\
\hline Union*Profit Sharing & $\begin{array}{l}.12 \\
(.08)\end{array}$ & $\begin{array}{l}.06 \\
(.06)\end{array}$ & $\begin{array}{l}.16^{*} \\
(.09)\end{array}$ & $\begin{array}{l}-.004 \\
(.06)\end{array}$ & $\begin{array}{c}.04 \\
(.06)\end{array}$ \\
\hline $\begin{array}{l}\text { Union* }>50 \% \text { of Non-Managerial } \\
\text { Workers Meeting Regularly in } \\
\text { Groups }\end{array}$ & $\begin{array}{l}.003^{*} \\
(.001)\end{array}$ & $\begin{array}{l}.0005 \\
(.0007)\end{array}$ & $\begin{array}{l}-.001 \\
(.001)\end{array}$ & $\begin{array}{l}-.0001 \\
(.0006)\end{array}$ & $\begin{array}{l}-.0004 \\
(.0008)\end{array}$ \\
\hline $\begin{array}{l}\text { Union* } * 20 \% \text { of Non-Managerial } \\
\text { Workers in Self-Managed Teams }\end{array}$ & $\begin{array}{l}.06 \\
(.10)\end{array}$ & $\begin{array}{l}.15^{*} \\
(.07)\end{array}$ & $\begin{array}{c}.05 \\
(.10)\end{array}$ & $\begin{array}{c}.08 \\
(.07)\end{array}$ & $\begin{array}{l}-.01 \\
(.08)\end{array}$ \\
\hline Adjusted R-Square & .5099 & .7140 & .5397 & .7671 & .5478 \\
\hline Number of observations & 187 & 201 & 177 & 233 & 219 \\
\hline
\end{tabular}

Note: Unless otherwise noted, variables refer to all workers in the establishment. Unionized $=1$ if an establishment answered yes to the question "Is your establishment represented by a union or unions?" Standard Errors in ()$,{ }^{*}$ denotes significant at the $10 \%$ level. All estimation has been done using the HuberWhite estimator of variance to correct standard errors. 
Table 5

Non-production/Production Workers Wage Differentials, 1996 Cross-Section

Variable Name

Relative Education

Relative Training

\% Minority

\% Women

\% Workers less than 1 year

Total Workers

Multiple Establishment

$>\mathbf{3 0} \%$ of Total Workers using

Computers

Count of workplace practices

Index of workplace practices

$>\mathbf{2 0} \%$ of Non-Managerial Workers involved in Self-Managed Teams $\mathbf{7 5 0} \%$ of Non-Managerial Workers

Meeting Regularly in Groups $>\mathbf{2 0} \%$ of Non-Managerial Workers involved in Job Rotation

$>\mathbf{5 0} \%$ of Production Workers Trained

Profit sharing

Unionization

Union*Profit Sharing

Union* $>\mathbf{5 0 \%}$ of Non-Managerial

Workers Meeting Regularly in Groups

Union* $>\mathbf{2 0 \%}$ of Non-Managerial

Workers in Self-Managed Teams

Adjusted R-Square

Number of observations
Basic Interactions

Count

Index

Worker characteristics

$\begin{array}{cc}.52 * & .52^{*} \\ (.26) & (.27) \\ -.02 & -.015 \\ (.02) & (.019) \\ .002 * & .002^{*} \\ (.001) & (.001) \\ .003 * & .003^{*} \\ (.001) & (.001) \\ .004 * & .004^{*} \\ (.002) & (.001) \\ -.00004 * & -.00004 * \\ (.00002) & (.00002) \\ -.05 & -.05 \\ (.05) & (.05) \\ -.10 * & \text { Technology } \\ (.03) & -.11 * \\ & (.03)\end{array}$

High Performance Work Systems

$\begin{array}{cc}.52 * & .52^{*} \\ (.26) & (.26) \\ -.01 & -.01 \\ (.02) & (.02) \\ .002 * & .002^{*} \\ (.001) & (.001) \\ .004 * & .004^{*} \\ (.001) & (.001) \\ .004 * & .004^{*} \\ (.002) & (.002) \\ -.00005^{*} & -.00005^{*} \\ (.00002) & (.00002) \\ -.05 & -.05 \\ (.05) & (.05)\end{array}$

$-.10^{*}$

$-.10 *$

(.03)

(.03)

.001

(.013)

$\begin{array}{cc}.03 & .05 \\ (.04) & (.04) \\ -.04 & .001 \\ (.03) & (.05) \\ .04 & .04 \\ (.04) & (.04) \\ -.002 & -.01 \\ (.04) & (.04) \\ -.03 & -.09 * \\ (.03) & (.04) \\ .003 & -.01 \\ (.04) & (.07) \\ & \text { Interactions }\end{array}$

.002

(.04)

.002

(.04)
$.13 *$

(.07)

$-.10$

(.08)

$-.03$

(.08)

$.3873 \quad 4051$

$209 \quad 209$
.3738

209
.3740

209

Note: Unless otherwise noted, variables refer to all workers in the establishment. Unionized $=1$ if an establishment answered yes to the question "Is your establishment represented by a union or unions?" 
Standard Errors in (), ${ }^{*}$ denotes significant at the $10 \%$ level. All estimation has been done using the HuberWhite estimator of variance to correct standard errors. All equations include two-digit industry dummies. 
Table 6

Non-production/Production Workers Wage Differentials, Establishment Fixed Effects

\begin{tabular}{|c|c|c|c|c|}
\hline Variable Name & Basic & Interactions & Count & Index \\
\hline \multicolumn{5}{|c|}{ Worker characteristics } \\
\hline Relative Education & $.59 *$ & $.52 *$ & $.59 *$ & $.60 *$ \\
\hline Relative Training & $\begin{array}{l}(.24) \\
-.015\end{array}$ & $\begin{array}{l}(.24) \\
-.02\end{array}$ & $\begin{array}{l}(.23) \\
-.01\end{array}$ & $\begin{array}{l}(.23) \\
-.013\end{array}$ \\
\hline & $(.019)$ & $(.02)$ & $(.02)$ & $(.017)$ \\
\hline$\%$ Minority & $\begin{array}{l}.001 \\
(.003)\end{array}$ & $\begin{array}{l}.001 \\
(.003)\end{array}$ & $\begin{array}{l}.001 \\
(.003)\end{array}$ & $\begin{array}{l}.001 \\
(.003)\end{array}$ \\
\hline \% Women & $\begin{array}{l}.001 \\
(.002)\end{array}$ & $\begin{array}{l}.001 \\
(.002)\end{array}$ & $\begin{array}{l}.001 \\
(.002)\end{array}$ & $\begin{array}{l}.001 \\
(.002)\end{array}$ \\
\hline$\%$ workers less than 1 year & $\begin{array}{l}-.001 \\
(.002)\end{array}$ & $\begin{array}{l}-.001 \\
(.003)\end{array}$ & $\begin{array}{l}-.001 \\
(.003)\end{array}$ & $\begin{array}{l}-.001 \\
(.003)\end{array}$ \\
\hline Total workers & $\begin{array}{l}-.00005^{*} \\
(.00003)\end{array}$ & $\begin{array}{l}-.000046 \\
(.00003)\end{array}$ & $\begin{array}{l}-.00002 \\
(.00003)\end{array}$ & $\begin{array}{l}-.00002 \\
(.00003)\end{array}$ \\
\hline \multicolumn{5}{|c|}{ Technology } \\
\hline $\begin{array}{l}>\mathbf{3 0} \% \text { of Total Workers using } \\
\text { Computers }\end{array}$ & $\begin{array}{l}-.02 \\
(.03)\end{array}$ & $\begin{array}{l}-.04 \\
(.03)\end{array}$ & $\begin{array}{l}-.01 \\
(.03)\end{array}$ & $\begin{array}{l}-.01 \\
(.03)\end{array}$ \\
\hline \multicolumn{5}{|c|}{ High Performance Work Systems } \\
\hline Count of workplace practices & & & $\begin{array}{l}.04 * \\
(.02)\end{array}$ & \\
\hline Index of workplace practices & & & & $\begin{array}{l}.04^{*} \\
(.02)\end{array}$ \\
\hline$>20 \%$ of Non-Managerial Workers & .06 & .06 & & \\
\hline involved in Self-Managed Teams & $(.05)$ & $(.07)$ & & \\
\hline$>50 \%$ of Non-Managerial Workers & -.01 & -.04 & & \\
\hline Meeting Regularly in Groups & $(.04)$ & $(.05)$ & & \\
\hline$>20 \%$ of Non-Managerial Workers & $.08^{*}$ & $.09 *$ & & \\
\hline involved in Job Rotation & $(.04)$ & $(.04)$ & & \\
\hline$>50 \%$ of Production Workers & .04 & .05 & & \\
\hline Trained & $(.04)$ & $(.04)$ & & \\
\hline Profit sharing & $\begin{array}{l}-.004 \\
(.05)\end{array}$ & $\begin{array}{l}-.07 \\
(.06)\end{array}$ & & \\
\hline Unionization & $\begin{array}{l}.05 \\
(.10)\end{array}$ & $\begin{array}{l}-.18 \\
(.16)\end{array}$ & $\begin{array}{l}.04 \\
(.10)\end{array}$ & $\begin{array}{l}.04 \\
(.10)\end{array}$ \\
\hline \multicolumn{5}{|c|}{ Interactions } \\
\hline Union*Profit Sharing & & $\begin{array}{l}.19 * \\
(.09)\end{array}$ & & \\
\hline Union $*>50 \%$ of Non-Managerial & & .09 & & \\
\hline Workers Meeting Regularly in & & $(.08)$ & & \\
\hline Groups & & & & \\
\hline Union* $>20 \%$ of Non-Managerial & & .01 & & \\
\hline Workers in Self-Managed Teams & 5230 & $\begin{array}{l}(.09) \\
5207\end{array}$ & 5250 & 5264 \\
\hline R-Square & & & .5259 & .5204 \\
\hline Number of observations & 138 & 138 & 138 & 138 \\
\hline
\end{tabular}


Note: Unless otherwise noted, variables refer to all workers in the establishment. Unionized $=1$ if an establishment answered yes to the question "Is your establishment represented by a union or unions?" Standard Errors in ()$,{ }^{*}$ denotes significant at the $10 \%$ level. All estimation has been done using the HuberWhite estimator of variance to correct standard errors. 
Table 7

Employment Reduction (1993-1996)

Logit Results

(Odds Ratios Presented, Z Values in Parentheses)

\begin{tabular}{|c|c|c|c|c|}
\hline Dependent Variable: & $\begin{array}{c}\text { Employment } \\
\text { down } 5 \% \text { or } \\
\text { more } \\
\end{array}$ & $\begin{array}{c}\text { Employment } \\
\text { down } 20 \% \text { or } \\
\text { more } \\
\end{array}$ & $\begin{array}{c}\text { Production Worker } \\
\text { Employment down } \\
5 \% \text { or more } \\
\end{array}$ & $\begin{array}{c}\text { Production Worker } \\
\text { Employment down } \\
20 \% \text { or more } \\
\end{array}$ \\
\hline \multicolumn{5}{|c|}{ Worker Characteristics } \\
\hline Average Education & $\begin{array}{c}.87 \\
(1.40)\end{array}$ & $\begin{array}{c}1.12 \\
(1.00)\end{array}$ & $\begin{array}{c}.52 * \\
(5.84)\end{array}$ & $\begin{array}{c}.55^{*} \\
(4.62)\end{array}$ \\
\hline$>50 \%$ Production Workers Trained & $\begin{array}{c}1.1 \\
(0.64)\end{array}$ & $\begin{array}{c}.90 \\
(0.53)\end{array}$ & $\begin{array}{c}1.03 \\
(0.17)\end{array}$ & $\begin{array}{c}.80 \\
(1.27)\end{array}$ \\
\hline$\%$ Workers less than 1 year & $\begin{array}{l}1.005 \\
(0.86)\end{array}$ & $\begin{array}{l}1.02 * \\
(2.24)\end{array}$ & $\begin{array}{l}1.003 \\
(0.45)\end{array}$ & $\begin{array}{l}1.0004 \\
(0.06)\end{array}$ \\
\hline \% Women & $\begin{array}{l}1.003 \\
(0.76)\end{array}$ & $\begin{array}{l}1.005 \\
(1.17)\end{array}$ & $\begin{array}{c}.999 \\
(0.24)\end{array}$ & $\begin{array}{l}1.0004 \\
(0.10)\end{array}$ \\
\hline$\%$ Minority & $\begin{array}{c}.999 \\
(0.43)\end{array}$ & $\begin{array}{c}.997 \\
(0.86)\end{array}$ & $\begin{array}{c}.999 \\
(0.21)\end{array}$ & $\begin{array}{c}.998 \\
(0.58)\end{array}$ \\
\hline Total workers & $\begin{array}{l}1.001^{*} \\
(5.24)\end{array}$ & $\begin{array}{c}1.0005^{*} \\
(4.38)\end{array}$ & $\begin{array}{c}1.0004 * \\
(3.89)\end{array}$ & $\begin{array}{c}1.0003^{*} \\
(2.73)\end{array}$ \\
\hline Multiple establishment & $\begin{array}{l}1.62^{*} \\
(2.81)\end{array}$ & $\begin{array}{l}1.55^{*} \\
(1.97)\end{array}$ & $\begin{array}{c}1.26 \\
(1.36)\end{array}$ & $\begin{array}{l}1.71^{*} \\
(2.67)\end{array}$ \\
\hline \multicolumn{5}{|c|}{ Technology } \\
\hline$>30 \%$ of Total Workers using Computers & $\begin{array}{c}.74^{*} \\
(1.84)\end{array}$ & $\begin{array}{c}.83 \\
(0.94)\end{array}$ & $\begin{array}{c}.82 \\
(1.20)\end{array}$ & $\begin{array}{c}.73^{*} \\
(1.71)\end{array}$ \\
\hline \multicolumn{5}{|c|}{ High Performance Work Systems } \\
\hline $\begin{array}{l}>20 \% \text { of Non-Managerial Workers in Self- } \\
\text { Managed Teams }\end{array}$ & $\begin{array}{c}1.12 \\
(0.49)\end{array}$ & $\begin{array}{l}1.92^{*} \\
(2.35)\end{array}$ & $\begin{array}{l}1.51^{*} \\
(1.71)\end{array}$ & $\begin{array}{l}1.72 * \\
(2.11)\end{array}$ \\
\hline Profit sharing & $\begin{array}{l}1.03 \\
(0.12)\end{array}$ & $\begin{array}{l}.79 \\
(0.77)\end{array}$ & $\begin{array}{l}.76 \\
(1.07)\end{array}$ & $\begin{array}{c}.89 \\
(0.40)\end{array}$ \\
\hline $\begin{array}{l}>20 \% \text { of Non-Managerial Workers } \\
\text { involved in Job Rotation }\end{array}$ & $\begin{array}{c}.97 \\
(0.20)\end{array}$ & $\begin{array}{l}.69^{*} \\
(1.70)\end{array}$ & $\begin{array}{c}.96 \\
(0.24)\end{array}$ & $\begin{array}{c}1.11 \\
(0.57)\end{array}$ \\
\hline \multicolumn{5}{|c|}{ Employee Voice } \\
\hline Unionized & $\begin{array}{c}1.04 \\
(0.10)\end{array}$ & $\begin{array}{c}.71 \\
(0.66)\end{array}$ & $\begin{array}{c}.75 \\
(0.73)\end{array}$ & $\begin{array}{c}.48 \\
(1.47)\end{array}$ \\
\hline $\begin{array}{l}>50 \% \text { of Non-Managerial Workers } \\
\text { Meeting Regularly in Groups }\end{array}$ & $\begin{array}{l}1.13 \\
(0.62)\end{array}$ & $\begin{array}{c}1.21 \\
(0.80)\end{array}$ & $\begin{array}{l}1.03 \\
(0.07)\end{array}$ & $\begin{array}{l}1.01 \\
(0.03)\end{array}$ \\
\hline \multicolumn{5}{|c|}{ Interactions } \\
\hline Union*Profit Sharing & $\begin{array}{c}.99 \\
(0.02)\end{array}$ & $\begin{array}{c}2.28 \\
(1.49)\end{array}$ & $\begin{array}{c}1.49 \\
(0.96)\end{array}$ & $\begin{array}{l}2.43^{*} \\
(1.70)\end{array}$ \\
\hline $\begin{array}{l}\text { Union*>50\% of Non-Managerial Workers } \\
\text { Meeting Regularly in Groups }\end{array}$ & $\begin{array}{c}.91 \\
(0.31)\end{array}$ & $\begin{array}{l}.44^{*} \\
(2.07)\end{array}$ & $\begin{array}{l}1.26 \\
(0.72)\end{array}$ & $\begin{array}{c}.98 \\
(0.05)\end{array}$ \\
\hline $\begin{array}{l}\text { Union* } * 20 \% \text { of Non-Managerial Workers } \\
\text { in Self-Managed Teams }\end{array}$ & $\begin{array}{c}.91 \\
(0.22)\end{array}$ & $\begin{array}{l}.78 \\
(0.52)\end{array}$ & $\begin{array}{l}.57 \\
(1.34)\end{array}$ & $\begin{array}{l}.40^{*} \\
(1.86)\end{array}$ \\
\hline $\begin{array}{l}\text { Pseudo R-Square } \\
\text { Number of observations }\end{array}$ & $\begin{array}{l}.0676 \\
840\end{array}$ & $\begin{array}{l}.0693 \\
840\end{array}$ & $\begin{array}{l}.0688 \\
840\end{array}$ & $\begin{array}{l}.0826 \\
840\end{array}$ \\
\hline establishments with dependent variable & $42.3 \%$ & $19.7 \%$ & $40.9 \%$ & $25.5 \%$ \\
\hline
\end{tabular}


Note: Unless otherwise noted, variables refer to all workers in the establishment. Unionized $=1$ if an establishment answered yes to the question "Is your establishment represented by a union or unions?" * denotes significant at the $10 \%$ level. All equations also include two-digit industry dummies. All explanatory variables were measured in 1993. 
${ }^{1}$ There have been numerous case studies (e.g. Krafcik (1988), Womack, Jones and Roos (1991), Ichniowski (1992), Berg, Appelbaum, Bailey and Kallenberg (1996), and Batt (1995)), intra-industry studies (e.g. Ichniowski, Shaw and Prennushi (1997), Arthur (1994), Kelly (1996), Bailey (1993) and Dunlop and Weil (1996)), and studies based on more nationally representative samples of firms (e.g. Ichniowski (1990), Huselid (1995), Black and Lynch (1996), Black and Lynch (2001), and Black and Lynch (2000)) that have all found a significant impact of these workplace practices on the productivity of U.S. businesses.

2. The first survey was designed by Lisa Lynch in collaboration with EQW Co-Directors Robert Zemsky and Peter Cappelli). The survey was supported by the Office of Educational Research and Improvement, US Department of Education.

3. Response rates are higher in manufacturing than in non-manufacturing establishments. The response rate in manufacturing in the 1994 survey was $66 \%$ while non-manufacturing was only $61 \%$. In 1997 , the response rate in manufacturing was $61 \%$ while only $52 \%$ in non-manufacturing. For more detailed information on response rates for the EQW-NES II see the following internet address: http://www.irhe.upenn.edu/cgi-bin/cat.pl\#nes1997.

${ }^{4}$ The training questions were at the end of the survey, which means the non-response rates to these questions are particularly high in the second interview.

${ }^{5}$ As a result, our final sample for the 1996 establishment level estimation is significantly smaller than the initial 2,479. Because of missing values, our cross-section wage equation has 524 establishments and our employment equations have 840 (missing values for employment could be replaced by the LRD values when available).

${ }^{6}$ We have also included other HPW practices in our estimation such as benchmarking, number of managerial levels, and employee-supervisors ratios but none of these practices were significant for the outcomes we examine in this paper.

${ }^{7}$ Note that we cannot distinguish whether this variable reflect the fact that firms with high turnover pay lower wages to each worker or firms with high turnover have a disproportionate number of new workers with less experiences which leads to lower average pay.

${ }^{8}$ Note that the sample size in the equations with all workers (and in the summary statistics in Table 1) differs from those equations estimated by occupation. The differences are driven entirely by missing variables. If one occupational wage is missing (in any occupation) and the establishment reported that they did in fact have workers in that occupation, we are unable to compute the average wage.

${ }^{9} \mathrm{We}$ also looked at composite measures of workplace practices, including a count of the number of practices within an establishment and an index created using factor analysis. Neither of these was significant. Full results are available from the authors upon request.

${ }^{10}$ Another possible specification might classify clerical/sales workers as low-skilled. The average education of clerical/sales workers in our sample (12.7 years) lies between that of production workers (11.8 years) and supervisors at (13.2 years). Because of this, we also ran our regressions using the alternative definition of low-skilled which included clerical/sales workers and obtained results entirely consistent with those presented in the paper.

${ }^{11}$ The index of workplace practices was constructed using principal components analysis, which showed one principal component with an eigenvalue greater than one; this one accounted for $30 \%$ of the total variance. 